\title{
「機能性表示食品制度」の留意点
}

国際医療福祉大学 大学院

縣俊彦

平成 27 年より論文などの科学的な根拠を示せ ば，国の審査なしに，健康への効用を表示できる 食品表示の新たな仕組み「機能性表示食品制度」 がスタートした。それまでにある特保（特定保健 用食品), 栄養機能食品に加えて，3つ目の食品制 度である，著者らもそれにかかわる機会が増えて きた。

この制度の特徵としてはガイドラインの存在が ある。これは 2014 年 7 月に公表の「食品の新たな 機能性表示制度に関する検討会」の報告書が ベースになっており食品表示基準で義務表示項目 が定められている.

機能性表示食品の定義は，食品表示基準の第二 条第一項にある。ここには，対象者，目的，対象 食品などが記されており，表示内容，安全性，機 能性，品質などの情報を販売日 60 日前に届け出る とし，概略は以下のごとくである.

【1. 対象食品となるかの判断】

機能性表示食品の対象となるかどうか，入口の 段階での要件が示されている。それは，

・疾病に罹患している者，未成年者，妊産婦（妊 娠を計画している者を含む. ) 及び授乳婦を対象 としていないか

・機能性関与成分として作用機序が明確であり, 定量, 定性確認が可能な成分か

・食事摂取基準が定められた栄養素でないか（な お，たんぱく質， $\mathrm{n}-6$ 系脂肪酸， $\mathrm{n}-3$ 系脂肪酸， 食物繊維, ビタミン A の 5 成分の構成成分は機 能性関与成分となりうる。たとえば各種アミノ 酸，ペプチド，EPA，DHA，難消化デキストリ ンなど.）

・特別用途食品, 栄養機能食品, アルコールを含 有する飲料ではないか

・脂質，飽和脂肪酸，糖類，ナトリウム等の過剩
摂取につながる食品ではないか

【2. 安全性の根拠】

1) 安全性評価に関するフローチャートが示され ている，最初に，届出者はどの食品でも食経 験の有無を確認する。ここで「無」の場合は, 公的機関のデータベースなどの 2 次情報を収 集して安全性を確認し，さらに情報が不足し ている場合は文献（1 次情報）を検索，安全 性試験を実施するなど安全性の確認が求めら れる。

2 ）機能性関与成分と医薬品の相互作用，機能性 関与成分を複数含む場合はその相互作用の有 無について，2 次情報または 1 次情報からの 安全性の確認が必要となる。

\section{【3. 生産・製造及び品質の管理】}

サプリメント形状の加工食品またはその他の加 工食品は，GMPや HACCPなどの衛生管理・品質 管理の体制がとることが望ましく，管理体制の届 出が求められる，生鮮食品も生産・採取，漁獲等 の衛生管理体制が必要となる。また，表示に記載 された成分が含まれているか分析も求められる. 機能性関与成分が質と量ともに含まれているか, 品質の担保が求められる。

\section{【4. 健康被害の情報収集体制】}

健康被害の発生の未然防止及び拡大防止を図る ため，届出者は情報収集し行政機関への報告を行 う体制の整備をする。

\section{【5. 機能性の根拠】}

次のいずれかによって，表示しょうとする機能 性の科学的根拠の評価が求められる.

1）最終製品を用いた臨床試験：トクホと同等の 水準の試験が求められる。試験の途中で都合 の良いデー夕に変更されないよう，事前登録 (UMIN 臨床登録システムなどを利用) が必要 
となる。また，臨床試験の結果を適切に評価 できるよう，国際的指針（CONSORT2010声 明）に準拠した査読付き論文を提出が求めら れる。

2 ）最終製品又は機能性関与成分に関する研究レ ビュー (システマティックレビュー) : 本制度 で新たに取り入れられた科学的根拠を示す手 法を明示する。

1）のように試験をするのではなく, 既存論文を データベースを用いて予め設定した方法で抽出し, 肯定的, 否定的な結果を統合し, 総合的に機能性 があるかどうかを評価する。ガイドラインでは, この方法が細かく記されている。評価の過程は, 他の人にも再現できるよう，全てのプロセスを整 理して情報開示することが求められる.

\section{【6. 表示の内容】}

義務表示項目は前述の食品表示基準の中にあ り, 詳細は今後, 施行通知および $\mathrm{Q} \& \mathrm{~A}$ で示すと

し，表示の留意事項についてまとめた.
ここでの最大の点は, 機能性評価について届け 出た内容を表示する際に, どの方法で科学的根拠 を評価したのか表示をすることを求めたことで, 下記の 3 つの構文が示されている.

ア最終製品を用いた臨床試験で，イ 最終製 品に関する研究レビューで, ウ 機能性関与成分 に関する研究レビューで, 科学的根拠を説明した 場合に分類される。

ウは最終製品だけでなく機能性関与成分だけで 科学的根拠が説明できるもので, その根拠が確か であればいろいろな食品に入れて届出をすること が可能である.

ウの表現をみたら,「企業が最終製品を用いてヒ 卜試験をしたものではなく，いろんな論文を集め て評価して表示をしたもの」となるので研究者, 届出者 (製品開発者), 消費者もその違いに留意す る必要がある. 特に届出者はシステマティックレ ビューにも精通し誤解を与え妨十分留意する 必要がある。 